\title{
Infrastructure deficiency and the performance of small- and medium-sized enterprises in Nigeria's Liberalised Economy
}

Authors:
Lawrence O. Obokoh ${ }^{1,2}$
Geoff Goldman'
Affiliations:
'Department of Business
Management, University of
Johannesburg, South Africa
2Department of Management
and Accounting, Obafemi
Awolowo University, Nigeria
Corresponding author:
Geoff Goldman,
ggoldman@uj.ac.za
Dates:
Received: 17 July 2015
Accepted: 11 Mar. 2016
Published: 28 July 2016
mobile phone or
to read online.
How to cite this article:
Obokoh, L.O., Goldman, G.,
2016, 'Infrastructure
deficiency and the
performance of small- and
medium-sized enterprises in
Nigeria's Liberalised
Economy', Acta Commercii
16(1), a339. http://dx.doi.
org/10.4102/ac.v16i1.339
Copyright:
C 2016. The Authors.
Licensee: AOSIS. This work
is licensed under the
Creative Commons
Attribution License.

Orientation: The paper investigates the situation facing SME's in Nigeria, who have to function in an environment with depleted infrastructure.

Research purpose: To examine the effects of infrastructure deficiency on the performance of manufacturing small and medium sized enterprises in Nigeria.

Motivation for the study: Low budgetary allocation by the Nigerian government toward investment and rehabilitation of infrastructure in favor of attempts to conform to the tenets of trade liberalisation, has created a situation where basic infrastructure provision is a huge challenge in the creation of SME's.

Research design, approach and method: A longitudinal approach was followed, where a survey was conducted amongst 500 SME's in Nigeria. To complement this, semi-structured interviews were conducted in 2007 and 2011 respectively.

Main findings: The deficiency in infrastructure negatively impacts the profitability and performance of SMEs, due to the high cost incurred by SMEs in the self-provision of infrastructure and distribution of finished goods. Furthermore, despite the successful privatisation of electricity production in November 2013, there is still no significant improvement in the power supply in Nigeria. However, the government has embarked on road rehabilitation to ease the transportation of goods and services.

Practical/managerial implications: The study uncovers the practical realities of the challenges faced by SME's operating in an environment with insufficient infrastructure, which is typical of much of the developing world.

Contribution/value add: The study highlights the necessity of sound infrastructure provision as a key factor to the development of SME's.

\section{Introduction}

This is a cross-sectional study that examined the effects of infrastructure deficiency on manufacturing small- and medium-sized enterprises' (SMEs) performance in Nigeria. This is on the backdrop of decades of persistent budget cuts for investment and rehabilitation of infrastructure by the Nigerian government in an attempt to conform to the tenets of economic liberalisation following a series of reforms that commenced in the late 1980s (Lee \& Anas 1992; Ogidan 2015).

Infrastructure is one of the most critical factors for economic development because it interacts with the economy through the production processes and changes in the quality of infrastructure available for production will greatly impact the production and performance of an organisation's levels of output, income, profits and employment creation in the economy. This is because of its direct link with the productivity (Adenikinju 2005; Kessides 1993). Despite the direct link between the availability and quality of infrastructure - electricity, portable water and poor road maintenance to economic development (Oseni \& Pollitt 2013) - the availability of infrastructure in most developing countries especially in the sub-Saharan African region leaves much to be desired (World Bank 2013, 2014). The gap in the availability of infrastructure in Nigeria has greatly impacted on the production processes in the manufacturing sector, especially the ability of the SMEs to compete in the global market.

The deficiency in the provision of infrastructure in Nigeria can be traced to the 1980s when the Nigerian government adopted the Structural Adjusted Programme (SAP). SAP prompted a series of economic reforms in Nigeria that resulted in the liberalisation of the economy by the Nigerian government. The policy was adopted as a result of the economic downturn in the1980s that 
resulted in balance of payment problems for Nigeria (Ikhide \& Yinusa 1998; Obiechina 2010). The reform was hinged on the neoliberal policy discourse and practices that spread across Africa during the 1980s to correct the adverse balance of payment in most African countries in a similar situation like Nigeria.

The policy resulted in the government ceding control of resource allocation in the economy to market forces (DesireAdom, Mahbub Morshed \& Sharma 2012; Ogunleye 2012). The aim of the policy was to create an enabling business environment for fair competition among firms operating in Nigeria. The policy also necessitated reduction in the cost of government through reduction in public expenditure (Mosley 1992). The budgetary cut in public expenditure negatively affected the quality of public infrastructure because of poor maintenance (Agboli \& Ukaegbu 2006; Lee \& Anas 1992). Presently, the budgetary gap in infrastructure allocation by the Nigerian government is put at \$2.4 trillion and has impacted on all facets of the Nigerian economy (Ogidan 2015).

However, scholars (Akinlo \& Odusola 2003; Jones 2010; Neu et al. 2010) suggest that such policies have not necessarily been successful in sub-Saharan Africa including Nigeria because of a lack of appropriate infrastructure and technology base, the high dependence of most economies on imported raw materials, immobility of production, dearth of skilled labour and inappropriate regulatory and high-risk environments (Mambula \& Sawyer 2004; Meagher 2006; Ojiako et al. 2013; Rankin, Söderbom \& Teal 2006). The sector most affected by inadequate infrastructure provision is the manufacturing sector, especially SMEs (Oseni \& Pollitt 2013). Unfortunately, one could infer that the Nigerian government misinterpreted the neoliberal policy framework of SAP in view of the cut in budgetary allocation for investment and rehabilitation of infrastructure.

In this article, our interest is on SMEs in the manufacturing sector, conceptualised as those businesses operating in the formal manufacturing sector with the number of employees not above 300 or their capital base not above N200 million. The interest in manufacturing SMEs is driven by their high sensitivity to external shock because of their limited resources (Cissokho \& Seck 2013; Vachani 1994; Van Wijnbergen 1986; Vickery 2008). Our interest in SMEs is further driven by the recognition among scholars (Rada 2007), of the urgent need for Nigeria to transform its manufacturing sector from a low to high value-added industry that catalyses economic growth (Alvarez \& Barney 2014; Brixiova 2010). This is because SMEs have a major role to play in the transformation process as enactors of innovation (Schumpeter 1950, 1961) and also the attainment of the United Nations blueprint on Millennium Development Goals and national economic development (Alvarez \& Barney 2014; Brixiova 2010; Shkolnikov \& Sullivan 2010).

Like the majority of African countries (see Global Entrepreneurship Monitor 2012; Nwankwo 2012), Nigeria's rapid economic growth is driven by a very vibrant SME sector which, however, continues to face various challenges
(Chu, Benzing \& McGee 2007; World Bank 2005). A recent report from the Global Entrepreneurship Monitor (2012) suggests that inadequate infrastructure remains one of the problematic factors hindering the development of small businesses in Nigeria.

To this end, the article raises the question as to how far the poor quality of infrastructure provision in Nigeria has affected the development and performance of manufacturing SMEs in view of the competitive liberalised economy of Nigeria?

Consequently, the objective of this article is to examine the effects of infrastructure deficiency on the development and performance of manufacturing SMEs in Nigeria. The focus period is 1980-2013. We formulated the following hypothesis:

$\left(H_{0}\right)$ There is no significant relationship between the state of infrastructure and the operational cost of SMEs.

$\left(H_{i}\right)$ There is significant relationship between the state of infrastructure and the operational cost of SMES (Cissokho \& Seck 2013).

The objective of the article was achieved through sampling of manufacturing SME owner-managers in Lagos State of Nigeria where the records of Central Bank of Nigeria and the Federal Bureau of Statistics survey (2012) indicates that Lagos State has the highest number of manufacturing SMEs in Nigeria with $17 \%$ of the national figure. The rest of this article is organised as follows. Following this introduction, in section 2 we explore the context of the study. In section 3, a review of related literature on SME access to infrastructure is presented. This is followed by section 4 where the methodology employed is set out. The discussion of the findings and concluding remarks are presented in Sections 5 and 6 , respectively.

\section{The study context and role of government}

The reason for the interest in SME is derived from the fact that major African countries such as Nigeria have been identified as a high-growth market, driven primarily by SME activities (Global Entrepreneurship Monitor 2012). However, some scholars such as Jackson, Amaeshi and Yavuz (2008) suggest that literature on entrepreneurship in Africa remains scant, leading to scholars such as Nwankwo (2012) to call for a re-scoping of business scholarship. The second driving factor behind the recurrence of the study of SME and infrastructure deficiency is because there are significant economic gains to be realised if the African sub-region improves the overall integration of its markets (Cissokho \& Seck 2013). But infrastructure development that links markets across countries faces political, institutional and economic challenges. These challenges tend to hold back investment into infrastructure, despite significant efforts within the region to develop regional infrastructure investment plans and promote an increased use of Public-Private Partnership approaches to mobilise private sector financing and expertise (World Bank 2014). 


\section{The role of government}

Underlying this entire discourse (see Goel \& Rishi 2012; Potter and Thompson 2011) is an acceptance of the regulatory and coordinating role of government in the stimulation of entrepreneurial activity. Increasingly, this role may prove important and will be required in developing countries, where the predominance of SMEs - although inferring vibrant entrepreneurial activity - is regarded by scholars (see Wiggins 1995) as indicative of any economy where the likelihood of business failure is particularly high. Another driver for government interest in the stimulation of entrepreneurial activity is that SMEs in developing countries are more likely to have a higher innovation propensity than those in developed countries (Naude 2013). Literature (Hall et al. 2012; McMullen 2011; Wong, Ho \& Autio 2005) suggests an endogenous interaction between innovation, entrepreneurial activity and economic growth. The implication of this is that governments in such economies may need to focus more on supporting the development of entrepreneurial activity by implementing policies that provide the enabling environment and emphasise reduction of uncertainty as well as transaction costs.

\section{Review of related literature}

The literature is replete with evidence that adequate infrastructure provision is a key element in the behind the border' agenda required for economic liberalisation to achieve its intended objective of efficient resource allocation, enhancement of investment, increased productivity and export growth (Adenikinju 2005; Agboli \& Ukaegbu 2006; Akinlo 2008; Amis \& Kumar 2000; Anas, Lee \& Murray 1996; Azémar \& Desbordes 2009; Lee \& Anas 1991, 1992; Nwankwo \& Richards 2004; World Bank 2014). The performance of SMEs is predicated on the availability of infrastructure which impacts on their competitiveness as infrastructure services affect other factors of production (Kessides 1993). However, the high set-up costs, long gestation periods and the social nature of infrastructure pay-offs make it unattractive to private sector investment (Adenikinju 2005; World Bank 2014). But with the low budgetary allocation to public goods by the Nigerian government following the adoption of SAP and the series of the reforms thereafter negatively affected the quantity and quality of infrastructure provision and has necessitated manufacturing businesses in Nigeria to embark on selfprovision, especially power for their production process (Owualah \& Obokoh 2008).

The inadequate provision of infrastructure is part of the reasons for the poor performance of Nigeria and other SSA countries in attracting foreign direct investments (Azémar \& Desbordes 2009; Dupasquier \& Osakwe 2006; World Bank 2014). A study by Akinlo (2008) of 11 sub-Saharan African countries including Nigeria indicates that social infrastructure is an important factor of production that impacts greatly on economic growth. The study report gives credence to Morley and Perdikis' study (2000) on trade liberalisation and government expenditure in Egypt, where it was demonstrated that export-led growth pursued by the government was hindered by the absence of essential infrastructure throughout the period investigated by the study.
With the prevailing liberal economic environment, both domestic and foreign investors would prefer to invest in regions or countries with adequate infrastructure services because improved infrastructure lowers production costs and increases market accessibility of businesses (Calderón \& Servén 2004; Wheeler \& Mody 1992). Where there is absence or inadequate provision of infrastructure, such as electricity and good roads, the enterprise resorts to self-provision, which the enterprise may not fully be able to internalise into its pricing structure. As a result, self-provision distorts the costs structure and the points of optimality where firms maximise profits subject to cost efficiency (Kimuyu \& Kayizzi-Mugerwa 1998).

Specifically, the level of infrastructure available to firms generates spillover externalities, with resultant higher industrial manufacturing cost of production. The result of Hulten, Bennathan and Srinivasan (2006) study on the state of infrastructure in India reveals substantial external effects exerted by infrastructure facilities on manufacturing productivity. The study separated the direct effects of roads and electricity, as mediated by the infrastructure services purchased by manufacturing industries along with other intermediate inputs, from the indirect effects, as measured by the impact of infrastructure capacity on the Solow productivity residual. They found that growth of road and electricity-generating capacity seems to have accounted for nearly half the growth of the productivity residual of India's registered manufacturing industries during a period of 20 years (1972-1992).

Calderón and Servén (2004) carried out an empirical evaluation of the impact of infrastructure development on economic growth and income inequality on 100 countries, spanning from 1960 to 2000 . They used the data set to estimate the empirical growth and inequality equations, including a standard set of control variables that were augmented by the infrastructure quantity and quality measures, which control the potential endogenous infrastructure indicators. The results suggest that the impact of infrastructure on economic growth is quite significant and that growth is accelerated while income inequality is reduced, when there is an increase in the availability and quality of infrastructure. The two results suggest that infrastructure development is highly effective to combat poverty especially in developing countries.

Ayogu (2007) highlighted highways and roads, mass-transit and airport facilities, educational buildings, electricity, gas and water supply facilities and distributional systems, waste treatment facilities, correctional institutions, police, fire service and judiciary as factors that can impact on the development efforts of developing countries. He stated that some infrastructural facilities, such as power and water do not possess the characteristics of non-rivalry and nonexclusion. Core infrastructure comprises highways, water, electricity and telecommunications. Public services provided by core infrastructure components may enter directly into private sector production and these components are expected to contribute most directly to private sector output. $\mathrm{He}$ concludes that infrastructure is important in different 
contexts and the level of its importance have not been fully appreciated by developing countries governments, in the sense that considerable resources have been expended on the provision of infrastructure with marginal success because of a lack of commitment and corruption.

In developing countries such as Nigeria, road and poor electricity supply are the twin major infrastructure problems confronting the business sector, including SMEs. In recent times, the introduction of the global system of the mobile communication helped in reducing to some extent the problem of communication in Nigeria, though at a great cost to subscribers. It has been observed that a typical Nigerian firm experiences power failure more than seven times per week without the benefit of prior warning (Adenikinju 2005). This imposes a huge cost on the SMEs arising from idle workers, spoiled materials, lost output, damaged equipment and costs of providing own electricity. The overall effect is the increase in business uncertainty, increase in operational costs, reduced competitiveness and lower return on investment (Nwankwo 2000). The growth potential of SMEs and even large-scale businesses has been seriously impaired by a lack of functional infrastructure (Adenikinju 2005; Cissokho \& Seck 2013). The infrastructure problem has become so deplorable that even some MNCs are closing down their factories and shifting operations to other countries.

Another study by Anas et al. (1996) was carried out in Nigeria and Thailand to document the qualitative and quantitative responses of manufacturing firms to infrastructure deficiencies in electricity, water, transport, telecommunications and waste disposal, as it affects their productivity and competitiveness. They found that manufacturers bear significant expenditures to offset deficiencies in publicly provided infrastructure services and that the changing public policy towards privately supplied infrastructure and the pricing of such infrastructure can be adjusted from its current forms to yield significant savings in social cost. While Thailand and Indonesia have already made significant strides in the direction of private sector participation in the provision of infrastructure, Nigeria still lags behind and will stand to benefit most from such a policy reform. They suggested that government policy should be directed towards the industrial organisation and pricing of infrastructure sectors. This will significantly help developing economies, including Nigeria where it has been realised that there are lots of important benefits in private sector participation in the provision of infrastructure service.

Adenikinju (2005) highlighted five means some firms in Nigeria cope with irregular electricity supply, which can be choice of location, factor substitution, private provision, choice of business and output reduction. While all these elements are presently observed among Nigerian firms, the most common approach has been through private provision. Electricity consumers have responded to Power Holding Company of Nigeria $(\mathrm{PHCN})^{1}$ inefficiency through self-generation of electricity. This is done by inputting the cost of self-generated

1.Power Holding Company of Nigeria is a public utility company with the monopoly of providing electric power to industries and household in Nigeria. With the
privatisation of power supply in Nigeria, the new companies are now referred to as privatisation of power supply in Niger
Electricity Distribution Companies. power as part of the cost of their total investment, which then raises significantly the set-up cost for manufacturing firms operating in the country. Lee and Anas (1991) reported that SMEs in Nigeria spend about $25 \%$ of the initial investment outlay on the self-provision of power generating plants. The existing electricity market structure allows PHCN to enjoy monopoly powers, yet it has so far failed to use the opportunity of large-scale electricity generation to lower supply cost compared with private provision.

A study was conducted by Lee and Anas (1992) to ascertain manufacturers' responses to the deficiencies of various public infrastructure services and the proportion of the costs of selfprovisions as an alternative that make up the total cost structure of the firms. The result revealed a general pattern of deficiencies and self-provision responses by the manufacturers across all five infrastructure subsectors. In almost all the infrastructure facilities, SMEs face higher unit costs than larger firms. They believed that improvements in public sector performance were likely to remain slow unless something drastic was done by the government. This means that manufacturing SMEs will have to bear the costs of selfprovision with the resultant detrimental effect on their local and international competitiveness.

\section{Methodology}

Different studies adopted various methods to estimate the cost of infrastructure deficiency on business in Nigeria electricity outage, absence of drinking water and poor road networks. Ukpong (1973) used the production function approach while Iyanda (1982) and Uchendu (1993) adopted the self-assessment methods to estimate the impact of power shortages; Lee and Anas (1991) used the self-assessment survey to measure the adaptive costs to the business sectors in coping with infrastructural deficiencies in Nigeria by investing in backups. The World Bank (1993) used adaptive costs to estimate cost of electricity failure on the Nigerian economy divided into consumer backup capacity, operating and maintenance costs of fuel, diesel and lubrication for auto-generators.

In this article, the researchers adopt a modified selfassessment and adaptive cost method, which requires respondents to fill out a questionnaire that gives the estimated cost effect on their operating cost and profit level on selfprovision of power and maintenance cost incurred on selfprovision of infrastructure resulting from the absence of infrastructure needed for their operations. The article partly adopted Ekpenyong's (2002) and Akinlo's (1996) questionnaire structure used to ascertain the impact of Structural Adjustment Programme on manufacturing firms in Nigeria. This is because results of both studies captured to a large extent the realities of the economic situation and the state of manufacturing in Nigeria following government low budgetary provision for infrastructure maintenance.

\section{Data collection and analysis}

This cross-sectional study used primary data obtained through initial distribution of 500 questionnaires to examine 
the effects of infrastructure deficiency on the performance of SMEs in Nigeria. Semi-structured interviews were also conducted in SMEs operating in Lagos State in 2007 and 2011. The initial questionnaire survey and semi-structured interview took 3 months between June and August 2007, and this study is a subset of the initial studies that examined the impact of economic liberalisation on SMEs in Nigeria. In February 2015, we conducted a follow up semi-structured interview using the log of SMEs kept during the earlier follow up semi-structured interview in 2011. The reason for the latest semi-structure interview is to find out whether there has been improvement in power supply to SMEs after the successful privatisation and handing over of the successor electricity generation and distribution companies to private operators by the Nigerian government in 2013.

The study, therefore, presents a composite picture of survey data, quantitative and qualitative, collected in 2007, 2011 and 2015.

Lagos State was chosen as the survey area because it is the centre of commercial activity in Nigeria (Apulu, Latham \& Moreton 2011) and has the highest concentration of SMEs and manufacturing establishments in Nigeria (Ajayi 2007). Also, the sample framework of the Federal Bureau of Statistics survey (2012) provided a further basis for the selection of Lagos State as the sample area because it accounts for the highest number of manufacturing SMEs output in Nigeria with $17 \%$ of the national figure. The state represents more than $66 \%$ of electricity consumption in the country because of the high population density and economic activities including manufacturing processes. Lagos State was divided into five survey areas (clusters) with ten survey attendants assigned to each area for ease of questionnaire administration. More questionnaires were distributed in areas with higher concentration of manufacturing SMEs. A log of all the questionnaires was kept to keep track of the number of questionnaires administered and returned.

The survey employed purposeful random sampling (Ikhide \& Yinusa 1998) because it targeted only manufacturing SMEs, irrespective of their line of products. In addition, the firms that the questionnaires were administered to were not predetermined, but were picked at the discretion of the survey attendants as far as the firms were located within the areas assigned to them. Only SMEs engaged in manufacturing activities were sampled and some of the returned questionnaires were invalidated because they were mistakenly administered to SMEs in the service sector, or because the sampled SMEs could not be classified as either small- or medium-sized enterprises because of the number of employees above 300 or their capital base above N200 million. From the initial 500 questionnaires distributed, a total of 430 questionnaires were returned out of which 369 were valid, representing $73.8 \%$ of the total sample. The 61 questionnaires were invalidated because some of the respondents were in the service sector.

The sampled SMEs spread across sectors, scales of operations so as to capture a significant number of manufacturing SMEs that to reflect the realities on ground in Nigeria. Besides, Nigeria is a Federation, so any policy that affects SMEs in Lagos State also affects SMEs in all the states of the Federation. This suggests that the realised sample response is considerably an acceptable representation of SMEs population in Nigeria.

Questionnaires were used to obtain general information about the entire population, while the semi-structured interviews were used to collect detailed and specific transaction data from SMEs that volunteered to present their transaction data for the research. The questionnaire and semi-structured interview methods was motivated by the indepth results of the findings of Akinlo (1996) and Ekpenyong (2002) that used either methods for their independent studies of the effects of SAP on manufacturing businesses in Nigeria. The questionnaire was pre-tested on 50 SMEs in Ibadan, Oyo State of Nigeria, prior to the questionnaire survey in 2007. This was undertaken to validate and test whether the survey questionnaire designed for the study was properly done to capture the information needed to achieve the objectives of the article. It was at the pilot stage that it was observed that most of SMEs that participated were not comfortable in giving out certain information such as sales and profit-andcost figures which were vital for attaining the objectives of the study.

The questionnaires were analysed with the aid of SPSS version 16.0 for an in-depth data assessment and graphical presentation. This enabled us carryout chi-square test and cross-tabulation of the data. The semi-structured interview was analysed using content analysis (Stemler 2001).

\section{Discussion of findings Questionnaire survey}

This section presents the analyses of the effects of infrastructure (power, communication, water supply, good roads, etc.) availability to manufacturing SMEs, which is a critical factor beyond the control of SMEs because it impacts on the competitiveness of manufacturing SMEs. In considering the infrastructures available to manufacturing SMEs, power supply, good access roads for easy transportation of raw materials and final products of SMEs and communication facilities were considered. The availability or absence of these facilities has a great impact on the competitiveness of SMEs' final product price, because of their direct and indirect effect on the operating cost of firms. The indirect effect of the absence of good access roads and communication facilities comes in the form of higher charges from the suppliers of raw materials, who charge SMEs more to meet the extra costs incurred in transporting raw materials to the manufacturing SMEs or the manufacturing SMEs, paying more to transport their goods from production location to the final market.

From Table 1, it is evident that the state of infrastructure in Nigeria is very poor and has affected the performance of manufacturing SMEs as indicated by majority of the 
TABLE 1: State and effect of infrastructure on operating cost and profit of sampled SMEs.

\begin{tabular}{lcc}
\hline Items under consideration & No. of firms & Percentage \\
\hline What is the state of infrastructure & 8 & 2.2 \\
Good & 33 & 8.9 \\
Adequate & 111 & 30.1 \\
Poor & 217 & 58.8 \\
Very poor & $\mathbf{3 6 9}$ & 100 \\
\hline Total & 292 & \\
\hline Effect on operating cost & 45 & 79.1 \\
Increase & 32 & 12.2 \\
Decrease & $\mathbf{3 6 9}$ & 8.7 \\
No effects & & 100 \\
\hline Total & 31 & \\
\hline Effect on profits & 290 & 8.4 \\
Increase & 48 & 78.6 \\
Decrease & $\mathbf{3 6 9}$ & 13.0 \\
No effects & & 100 \\
\hline Total & 345 & 93.5 \\
SMEs that generate own power & 23 & 6.2 \\
Yes & 1 & 0.3 \\
No & $\mathbf{3 6 9}$ & $\mathbf{1 0 0}$ \\
Others & & \\
\hline Total & & \\
\hline Source: Surv & & \\
\hline
\end{tabular}

Source: Survey 2007-2011

respondents. From the table, $58.8 \%$ believe that the state of infrastructure available to them is very poor while $30.1 \%$ said it is poor. When the two views of respondents who believed that the state of infrastructure is very poor and poor are put together, it then shows that $88.9 \%$ asserted that the state of infrastructure is poor in Nigeria. An insignificant $2.2 \%$ of the respondents indicated that infrastructure was good, while $8.9 \%$ believed it was adequate. This article appreciates the fact that it was possible to have SMEs that believes the state of infrastructure is good or adequate for them because of the type of products they are engaged in and the production method. For instance, those sampled SMEs engaged in printing, who still make use of manual printing machines for their production process, and whose clients come in to collect the final jobs when they are ready, are indifferent about the number of hours they have power supply.

When the effects of the state of infrastructure on the operating costs and profits of sampled SMEs were taken into consideration, the result reveals a poor competitive position of manufacturing SMEs, against well-established foreign firms that operate in the liberalised economic environment of Nigeria. As can be seen from Table 1, a 79.1\% majority of respondents asserted that the poor state of infrastructure actually increased their cost of operation. This is further confirmed by the $93.5 \%$ of the respondents who said they generated their own power. This also partly explains the reason for SMEs high operational costs. Only 8.7\% claimed that the state of infrastructure did not have any effects on their operating costs. Generally, the cost of buying and maintaining power generating sets is quite high, because of import costs in view of the devalued Naira and the cost of fuel. The respondents also noted that there was always scarcity of fuel, which has been a recurring problem in Nigeria, especially as a country that is ranked the seventh largest producer of crude oil in the world.

The reported high operating costs by the majority of the respondents also reflects on the number of sampled SMEs that reported a decrease in profit. The decrease in profit reported by the respondents particularly reflects the liberalised competitive market conditions in Nigeria after the implementation of the economic liberalisation policy. The competitive market situation made it impossible for most SMEs to transfer some of their costs to the final consumers. But very few manufacturing SMEs produce consumable goods that have a very short shelf life and which cannot be easily imported without heavy losses because of their perishable nature, for instance those in the food and beverage industry. Although $8.4 \%$ did report they experienced an increase in profits despite the competition, a 78.6\% majority reported a decrease in profits, while $13 \%$ did not notice any changes to their profit situation.

Furthermore, $92.5 \%$ believed that it would be cheaper and cost effective if there is a regular power supply from the Power Holding Company. This is because $95.9 \%$ believe that their performance would greatly improve when the state of infrastructure such as power supply, good access roads and communication facilities available to them are improved. Most of them, apart from ticking the required box in the questionnaire, volunteered additional information on how their profits have been negatively affected because of the poor state of infrastructure.

The respondents' perception of the state of infrastructure was cross-tabulated with the rankings of respondents' state of infrastructure, to find out how the state of infrastructure affects the operational cost of each category. Here the dependent variable is the operating cost, because it is the means by which we measure the extent to which the availability or otherwise of infrastructure (power, communication, water supply, good roads, etc.) impacts on the performance of SMEs.

As can be seen from Table 2, only $36.4 \%$ of the total group of SMEs that ranked the state of infrastructure as adequate agreed that the state of infrastructure increased their operational costs. Majority of all the SMEs in each of the other rankings agreed that the poor state of infrastructure increased their operating costs. The chi-square crosstabulation yielded a significant $P$-value $(0.05>0.001)$, which shows that if the condition of infrastructure available to SMEs at the moment is improved upon by the Nigerian government, the operation costs in terms of self-provision of some facilities will be greatly reduced.

Also, the cross-tabulation of the ranking of the state of infrastructure and the profits of sampled SMEs was also performed to know how the state of infrastructure impacted on the profits of different group of SMEs, based on their opinion of the state of infrastructure. 
The result of the cross-tabulation in Table 3 shows a different and interesting picture in the sense that $50 \%$ of those SMEs that said the state of infrastructure is good indicated that their profits increased, while $25 \%$ reported either a decrease in profits or no effect on their profits, respectively. A different scenario can be noticed in the group that said the state of infrastructure was adequate, as a $48.5 \%$ majority in this group indicated the state of infrastructure did not have any effect on their profits. The explanation for this is that the few SMEs in this group are used to the self-provision of their power supply, trucks for the transportation of their final products and have their own dedicated radio communication system. They were able to transfer most of their costs to the final consumers because their products do not have easy substitutes, for instance, those already established dairy producers that also produce sachet water as a complementary by-product. On the other hand, $81.1 \%$ and $87.1 \%$ of the group that ranked the state of infrastructure as poor and very poor, respectively, indicated that the state of infrastructure adversely affects their profits. The chi-square value produced a significant $P$-value $(0.05>0.001)$, which indicates how infrastructure adversely affects manufacturing businesses in Nigeria.

\section{Test of hypothesis}

This section reports the results of the test of the null hypothesis and the alternate hypothesis proposed in the article. The hypothesis was tested using binomial and chisquare $\left(\chi^{2}\right)$ test of significance. A two-tailed test was also used as test of direction of the variables because we were not sure of the direction the variable will follow (Field 2005).

$\left(H_{0}\right)$ There is no significant relationship between the state of infrastructure and the operational cost of SMEs.

$\left(H_{i}\right)$ There is significant relationship between the state of infrastructure and the operational cost of SMEs.

From Table 4, the results reveals a significant negative correlation between the state of infrastructure and operational costs after the implementation of economic liberalisation $\chi^{2}(6)=97.278, P<0.001$. The two variables perfectly correlate

with each other with $R=1$, as can be seen along the diagonal of the table. The state of infrastructure is negatively correlated with operational costs of SMEs with a Pearson correlation coefficient of $r=-0.286$ with less than 0.001 probability that a correlation coefficient of this magnitude would have occurred by chance in a sample size of 369 is zero, as indicated by the asterisks after -0.286 in the table. So there is confidence that the relationship between state of infrastructure and the operational cost is genuine. The mean of 97.278 with a very small variance of -0.286 and degree of freedom six shows the strength of the state of infrastructure and operational cost as they relate to each other.

The negative correlation coefficient of -0.286 indicates that the more the state of infrastructure deteriorates, the higher would be the operational cost of SMEs. Conversely, if the state of infrastructure is improved, the lesser would be the operational cost of SMEs.

So we reject the null hypothesis that there is no significant relationship between the state of infrastructure and the operational cost of SMEs in Nigeria after economic liberalisation. The economic liberalisation policy actually encouraged privatisation and the primacy of the private sector and the market forces over government. This has led to the low budgetary outlay towards expansion and

TABLE 4: Comparison of the state of infrastructure and the operational cost of SMEs.

\begin{tabular}{lcc}
\hline Variables & SMEs profit & State of infrastructure \\
\hline SMEs profits & 1 & $-0.286^{*}$ \\
Pearson's $R$ & - & 0.000 \\
Sig. (2-tailed) & - & 97.278 \\
Chi-square value & - & 6 \\
Degree of freedom & 369 & 369 \\
$N$ & & \\
State of infrastructure & $-0.286^{*}$ & 1 \\
Pearson correlation & 0.000 & - \\
Sig. (2-tailed) & 97.278 & - \\
Chi-square value & 6 & - \\
Degree of freedom & 369 & 369 \\
$N$ &
\end{tabular}

TABLE 2: Showing the cross-tabulation of SMEs ranking of the state of infrastructure and operating cost.

\begin{tabular}{|c|c|c|c|c|c|}
\hline \multirow{2}{*}{$\begin{array}{l}\text { Effects of the state of infrastructure } \\
\text { on SMEs operational costs }\end{array}$} & \multicolumn{4}{|c|}{ SMEs ranking of state of infrastructure } & \multirow[t]{2}{*}{ Total } \\
\hline & Good & Adequate & Poor & Very poor & \\
\hline Increased operational cost & $87.5 \%(7)$ & $36.4 \%(12)$ & $81.1 \%(90)$ & $84.3 \%(183)$ & $79.1 \%(292)$ \\
\hline Decreased operational cost & $12.5 \%(1)$ & $9.1 \%(3)$ & $13.5 \%(15)$ & $12.1 \%(26)$ & $12.2 \%(45)$ \\
\hline No effect & - & $54.5 \%(18)$ & $5.4 \%(6)$ & $3.7 \%(8)$ & $8.7 \%(32)$ \\
\hline Total & $100 \%(8)$ & $100 \%(33)$ & $100 \%(111)$ & $100 \%(217)$ & $100 \%(369)$ \\
\hline
\end{tabular}

Source: Table 1

TABLE 3: Showing the cross-tabulation of SMEs ranking of the state of infrastructure and the profits of sampled SMEs.

\begin{tabular}{|c|c|c|c|c|c|}
\hline \multirow{2}{*}{$\begin{array}{l}\text { Effects of the state of } \\
\text { infrastructure on SMEs profits }\end{array}$} & \multicolumn{4}{|c|}{ SMEs ranking of state of infrastructure } & \multirow[t]{2}{*}{ Total } \\
\hline & Good & Adequate & Poor & Very poor & \\
\hline Increased profit & $50 \%(4)$ & $24.4 \%(8)$ & $5.6 \%(6)$ & $6.0 \%(13)$ & $8.4 \%(31)$ \\
\hline Decreased profits & $25 \%(2)$ & $27.3 \%(9)$ & $81.1 \%(90)$ & $87.1 \%(189)$ & $78.6 \%(290)$ \\
\hline No effect & $25 \%(2)$ & $48.5 \%(16)$ & $13.5 \%(15)$ & $6.9 \%(15)$ & $13.0 \%(48)$ \\
\hline Total & $100 \%(8)$ & $100 \%(33)$ & $100 \%(111)$ & $100 \%(217)$ & $100 \%$ (369) \\
\hline
\end{tabular}

Source: Table 1 
rehabilitation of infrastructure by government in Nigeria (Agboli \& Ukaegbu 2006; Lee \& Anas 1992).

\section{Report of semi-structured follow up interview}

With the successful privatisation and handover of the successor electricity generation and distribution companies to private operators by the Nigerian government in 2013, we conducted a follow up semi-structured interview on two out of the five survey areas (clusters) of Lagos State, namely the Oshodi-Isolo and Ikeja-Ogba areas. The area is noted for high concentration of manufacturing and commercial activities in the state. It was amazing that out of the expected 19 SMEs previously located in the area, we were able to meet five of the firms. Most of the locations have new retail shops in the buildings previously occupied by those manufacturing SMEs. The new occupants did not have any information about the previous business, while some locations were still not occupied by any business. We cannot infer whether those businesses closed down because of infrastructure deficiency or simply relocated. A more shocking discovery is the desolate nature of the once busy Oba Akran avenue, which is now less busy because of the relocation of some of the multinational companies to neighbouring countries because of the high cost of power. Little wonder that we could not find most of the manufacturing SMEs previously located in the area.

However, the managers of the five firms we were able to locate said nothing much has changed because they still expend substantial amount of their profit to generate their own power. But the long black out previously experienced that run into weeks at times months prior to privatisation of electricity distribution has reduced. The reduced outage time still does not hide the fact that they spend on the average N55,000 monthly for fuel to power their generator sets. This assertion supports the recent statistics released by the Centre for Management Development that revealed the fact that about 60 million Nigerians spent N1.6 trillion on generators annually to generate their own electricity.

In terms of good access roads, we found that the state government has embarked on the expansion and rehabilitation of some roads within the Lagos metropolis. This has opened up and eased traffic movement in some areas while some roads in the Oshodi-Isolo and Ikeja-Ogba areas of Lagos State seem to be neglected. The very poor state of the roads has made the cost of transportation of both raw materials and finished goods very high for individual household and businesses alike.

\section{Concluding remarks}

The liberalisation policy required the Nigerian government to privatise all government parastatals and hands off direct participation in the provision of public goods, in order to cut down on public expenditures in line with the tenets of the reform process. The policy prompted the government to privatise most of the public utility companies to allow private ownership, as it was assumed that this would free more resources for other government functions and improve the efficiency in the delivery of service to customers. Ever since, the state of infrastructure has deteriorated because of the lack of private investment in these services partly because of the large initial capital outlay required and the length of time it takes to recoup investment. The lack of interest of the private sector and the government's low budgetary allocation in the years following the liberalisation policy, led to the very poor state of infrastructure in Nigeria, which includes electricity, telecommunication and access roads.

The poor state of infrastructure resulted in most manufacturing SMEs providing their own electricity to power their production process. This self-provision of power by manufacturing SMEs as a result of the poor state of infrastructure affects their profitability, productivity, wealth creation and their capacity to create employment in Nigeria. In addition, it has to a large extent compromised their chances of survival and competitive ability in the liberalised economic environment. This finding is consistent with the reports of Lee and Anas (1992), Anas et al. (1996), Mambula (2004), Adenikinju (2005), Agboli and Ukaegbu (2006) and Owualah and Obokoh (2008) report on the state of infrastructure in Nigeria and how it has affected the manufacturing sector.

The Nigerian government has in recent times budgeted a substantial amount of money as noted by Ayogu (2007), but the effect has not been felt as frequent power cuts are still the order of the day in Nigeria, which was the majority view of the respondents. This has made it difficult to realise any gain from the liberalisation policy. This situation is similar to that reported by Morley and Perdikis (2000) in a study on trade liberalisation and government expenditure in Egypt, where it was found that export-led growth pursued by the government was hindered by the absence of essential infrastructure throughout the period investigated by the study.

The absence of infrastructure and special SMEs funds faced by SMEs before liberalisation, still persisted after the implementation of the policy. The problem of infrastructure was even more compounded with the cut in the budgets for the provision of public service utilities by the government. This is evidenced from the present poor state of infrastructure. The poor state of infrastructure has also significantly affected SMEs costs and their competitiveness, because they had to embark on self-provision of some of these infrastructures.

\section{Acknowledgements Competing interests}

The authors declare that they have no financial or personal relationships which may have inappropriately influenced them in writing this article. 


\section{Authors' contributions}

L.O.O. conducted the research as an expansion of his PhD study and also compiled the initial draft of the manuscript. G.G. helped with the conceptualisation of the manuscript and refined the initial draft into the submitted manuscript.

\section{References}

Adenikinju, A., 2005, Analysis of the cost of infrastructure failures in a developing economy: The case of the Electricity Sector in Nigeria, AERC Research Paper 148 African Economic Research Consortium, Nairobi.

Agboli, M. \& Ukaegbu, C.C., 2006, 'Business environment and entrepreneurial activity in Nigeria: Implications for industrial development', Journal of Modern African Studies 44(1), 1-30. http://dx.doi.org/10.1017/S0022278X05001394

Ajayi, O.E., 2007, User acceptability of sustainable soil fertility technologies: Lessons from farmers' knowledge, attitude and practice in Southern Africa. Journal of Sustainable Agriculture. Vol. 30(3): $21-40$.

Akinlo, A.E. (1996), "The Impact of Adjustment Programme on Manufacturing Industries in Nigeria, 1986-1991: A Sample Study." African Development Review, 16, 73-93.

Akinlo, A.E., 2008, 'Energy consumption and economic growth: Evidence from 11 SubSahara African countries', Energy Economics 30, 2391-2400. http://dx.doi. org $/ 10.1016 / j$.eneco.2008.01.008

Akinlo, A.E. \& Odusola, A.F., 2003, 'Assessing the impact of Nigeria's Naira depreciation on output and inflation', Applied Economics 35(6), 691-703. http://dx.doi.org/ $10.1080 / 0003684032000056823$

Alvarez, S. \& Barney, J., 2014, 'Entrepreneurial opportunities and poverty alleviation' Entrepreneurship Theory and Practice 38(1), 159-184. http://dx.doi.org/10.1111/ etap.12078

Amis, P. \& Kumar, S.I., 2000, 'Urban economic growth, infrastructure and poverty in India: Lessons from Visakhapatnam', Environment \&Urbanization 12(1), 185-196. http://dx.doi.org/10.1177/095624780001200113

Anas, A., Lee, K.S. \& Murray, M., 1996, Infrastructure bottlenecks, private provision, and industrial productivity: A study of Indonesian and Thai Cities, Policy Research Working Paper 1603, Infrastructure and Energy Division, The World Bank Operations Evaluation Department, Washington DC.

Apulu, I., Latham, A. \& Moreton, R., 2011, 'Factors affecting the effective utilisation and adoption of sophisticated ICT solutions: Case studies of SMEs in Lagos, Nigeria', Journal of Systems and Information Technology 13(2), 125-143. http:// dx.doi.org/10.1108/13287261111135972

Ayogu, M., 2007, 'Infrastructure and economic development in Africa: A review', Journal of African Economies 16(AERC Supple 1), 75-126. http://dx.doi.org/ 10.1093/jae/ejm024

Azémar, C. \& Desbordes, R., 2009, 'Public governance, health and foreign direct investment in Sub-Saharan Africa', Journal of African Economies, Vol 18(4), 667-709. http://dx.doi.org/10.1093/jae/ejn028

Brixiova, Z., 2010, 'Unlocking productive entrepreneurship in Africa's least developed countries', African Development Review 22(3), 440-451. http://dx.doi.org/ 10.1111/j.1467-8268.2010.00255.x

Calderón, C. \& Servén, L., 2004, The effects of infrastructure development on growth and income distribution, Policy Research Working Paper WPS 3400, The World Bank, Washington, DC.

Chu, H.M., Benzing, C. \& McGee, C., 2007, 'Ghanaian and Kenyan Entrepreneurs: A comparative analysis of their motivations, success characteristics and problems',
Journal of Developmental Entrepreneurship 12(3), 295-322. http://dx.doi. Journal of Developmental Entrepre
org/10.1142/S1084946707000691

Cissokho, L. \& Seck, A., 2013, Electric power outages and the productivity of small and medium enterprises in Senegal, Investment Climate and Business Environment Research Fund Report No. 77/13. TrustAfrica, Dakar.

Desire-Adom, A., Mahbub Morshed, A.K.M. \& Sharma, S.C., 2012, Sources of real exchange rate volatility in Africa: The case of ECOWAS', African Development Review 24(1), 79-92. http://dx.doi.org/10.1111/j.1467-8268.2012.00306.x

Dupasquier, C. \& Osakwe, P.N., 2006, 'Foreign direct investment in Africa: Performance, challenges and responsibilities', Journal of Asian Economics 17, 241-260. http:// dx.doi.org/10.1016/j.asieco.2005.07.002

Ekpenyong, D.B., 2002, 'Performance of small scale enterprises in Nigeria during the structural adjustment programme implementation: Survey findings', Journal of Financial Management \& Analysis 15(1), 38-50.

Federal Bureau of Statistics, 2012, 'FG releases first National Survey on SMEs Survey shows 99 per cent of firms are micro enterprises', This Day Newspaper, Nigeria. 20 July 2012, available at http://allafrica.com/stories/201207200143.htm

Field, A.P., 2005, Is the meta-analysis of correlation coefficients accurate when population correlations vary?. Psychological methods, 10(4), p.444.

Global Entrepreneurship Monitor, 2012, African entrepreneurship: Sub-Saharan African regional report, Business School, London.

Goel, G. \& Rishi, M., 2012, 'Promoting entrepreneurship to alleviate poverty in India: An overview of government schemes, private-sector programs, and initiatives in the citizens' sector', Thunderbird International Business Review 54(1), 45-57. http://dx.doi.org/10.1002/tie.21437
Hall, J., Matos, S., Sheehan, L. \& Silvestre, B., 2012, 'Entrepreneurship and innovation at the base of the pyramid: A recipe for inclusive growth or social exclusion?' Journal of Management Studies 49(4), 785-812. http://dx.doi.org/10.1111/j. Journal of Management

Hulten, C.R., Bennathan, E. \& Srinivasan, S., 2006, 'Infrastructure, externalities, and economic development: A study of the Indian manufacturing industry', The World Bank Economic Review 20(2), 291-308. http://dx.doi.org/10.1093/wber//hj007

Ikhide, S.I. \& Yinusa, D.O., 1998, The impact of financial liberalisation on the finance of small and medium scale enterprises in Nigeria research report 12, Development Policy Centre, Ibadan.

Iyanda, O., 1982, 'Cost and marketing implications of electric power failures on high income households in Lagos', The Nigerian Journal of Economic and Social Studies 24(2), 169-184.

Jackson, T., Amaeshi, K. \& Yavuz, S., 2008, 'Untangling African indigenous management Multiple influences on the success of SMEs in Kenya', Journal of World Business 43(3), 400-416. http://dx.doi.org/10.1016/j.jwb.2008.03.002

Jones, J.L., 2010, 'Nothing is straight in Zimbabwe': The rise of the Kukiya-kiya economy 2000-2008', Journal of Southern African Studies 36(2), 285-299. http:// dx.doi.org/10.1080/03057070.2010.485784

Kessides, C., 1993, The contributions of infrastructure to economic development: A review of experience and policy implications, World Bank Discussion Papers No. 213, the World Bank, Washington DC

Kimuyu, P. and Kayizzi-Mugerwa, S. (1998), Enterprise response to deficient infrastructure in Kenya, IPAR Discussion Paper No.DP/011198, Institute of Policy infrastructure in Kenya, IPAR Discussion
Analysis and Research, Nairobi, Kenya.

Lee, K.S. and Anas, A., 1991, 'Manufacturers' responses to infrastructure deficiencies in Nigeria: Private alternatives and policy options', in A. Chibber \& S. Fischer (eds.), Economic Reform in Sub-Saharan Africa, A World Bank Symposium. The World Bank, Washington DC, 106-121.

Lee, K.S. and Anas, A., 1992, 'Costs of deficient infrastructure: The case of Nigerian manufacturing', Urban Studies 29(7), 1071-1092.http://dx.doi.org/10.1080/ 00420989220081051

Mambula, C.J., 2004, 'Relating external support, business growth and creating strategies for survival: A comparative case study analyses of Small Manufacturing Firms (SMFs) and entrepreneurs', Small Business Economics 22, 83-109. http:// dx.doi.org/10.1023/B:SBEJ.0000014450.16699.c6

Mambula, C.J. \& Sawyer, F.E., 2004, 'Acts of entrepreneurial creativity for business growth and survival in a constrained economy: Case study of Small Manufacturing Firm (SMF)', International Journal of Social Economics 31(1/2), 30-55. http://dx. doi.org/10.1108/03068290410515402

McMullen, J.S., 2011, 'Delineating the domain of development entrepreneurship: A market-based approach to facilitating inclusive economic growth' Entrepreneurship Theory and Practice 35(1), 185-193. http://dx.doi.org/10.1111/ j.1540-6520.2010.00428.x

Meagher, K., 2006, 'Social capital, social liabilities, and political capital: Social networks and informal manufacturing in Nigeria', African Affairs 105(421), 553-582. http:// dx.doi.org/10.1093/afraf/adi123

Morley, B. \& Perdikis, N., 2000, 'Trade liberalisation, government expenditure and economic growth in Egypt', Journal of Development Studies 36(4), 38-54. http:// dx.doi.org/10.1080/00220380008422636

Mosley, P., 1992, 'Policy-making without facts: A note on the assessment of structural adjustment policies in Nigeria, 1985-1990', African Affairs 91(363), 227-240.

Mosley, P., 1999, 'Micro-macro linkages in financial markets: The impact of financial liberalisation on access to rural credit in four African countries', Journal of International Development 11, 367-348. http://dx.doi.org/10.1002/(SICI)10991328(199905/06)11:3<367::AID-JID589>3.0.CO;2-W

Naude, W. (2013), Entrepreneurship and economic development: Theory, evidence and policy, IZA Discussion Paper, No. 7507. Maastricht Economic and social Research institute on Innovation and Technology, Maastricht.

Neu, D., Rahaman, A.S., Everett, J. \& Akindayomi, A., 2010, 'The sign value of accounting: IMF structural adjustment programs and African banking reform' Critical Perspectives on Accounting 21(5), 402-419. http://dx.doi.org/10.1016/j. сра.2008.06.002

Nwankwo, S., 2000, 'Assessing the marketing environment in sub-Saharan Africa: Opportunities and threats analysis', Marketing Intelligence \& Planning 18(3) 144-153. http://dx.doi.org/10.1108/02634500010327935

Nwankwo, S., 2012, 'Renascent Africa: Rescoping the landscape of international business', Thunderbird International Business Review 5(44), 405-409. http://dx. doi.org/10.1002/tie.21472

Nwankwo, S. \& Richards, D., 2004, 'Institutional paradigm and the management of transitions: A sub-Sahara African perspective', International Journal of Socia Economics 31(1/2), 111-130. http://dx.doi.org/10.1108/03068290410515457

Obiechina, M.E., 2010, 'Capital flows and financial crises: Policy issues and challenges for Nigeria', Central Bank of Nigeria Economic and Financial Review 48(1), 93-112.

Ogidan, A., 2015, 'Government moves to bridge $\$ 2.4$ trillion infrastructure funding gap', The Guardian-Business News, 25 February, 2015, Vol. 31, p. 19.

Ogunleye, E.O., 2012, 'Exchange rate deregulation and industrial performance in Nigeria: 1975-2006', European Journal of Social Sciences 29(1), 96-105.

Ojiako, U., Manungo, T., Chipulu, M. \& Johnson, J. 2013, 'The impact of regulation on risk perception: Evidence from the Zimbabwean Banking Industry', African Development Review 25(3), 276-288. http://dx.doi.org/10.1111/j.1467-8268. 2013.12029.x

Oseni, M.O. \& Pollitt, M.G., 2013, The economic costs of unsupplied electricity: Evidence from backup generation among African firms, Energy Policy Research 
Group Working Paper 1326, Cambridge Working Papers in Economics 1351, Cambridge University Press, Cambridge

Owualah, S.I. \& Obokoh, L.O., 2008, 'Tackling youth restiveness in the Niger Delta Region of Nigeria through entrepreneurship', Journal of Enterprising Communities: People and Places in the Global Economy 2(2), 168-179. http://dx.doi. org/10.1108/17506200810879989

Potter, J., \& Thompson, J. (2011), Government responses to the impact of the globa crisis on finance for young and small enterprises. Strategic Change, 20, 145-159. doi:10.1002/jsc.892

Rada, C., 2007, 'Stagnation or transformation of a dual economy through endogenous productivity growth', Cambridge Journal of Economics, 31, 711-740. http:// dx.doi.org/10.1093/cje/bem004

Rankin, N., Söderbom, M. \& Teal, F., 2006, 'Exporting from manufacturing firms in subSaharan Africa', Journal of African Economies 15(4), 671-687. http://dx.doi. org/10.1093/jae/ejk014

Schumpeter, J.A., 1950, Capitalism, socialism and democracy, Harper \& Row, New York.

Schumpeter, J.A., 1961, The theory of economic development, Oxford University Press, New York.

Shkolnikov, A. \& Sullivan, J.D., 2010, 'Meeting the institutional challenges of the millennium development goals', Development 53(1), 58-63. http://dx.doi. millennium development

Stemler, S., 2001, 'An overview of content analysis', Practical Assessment, Research \& Evaluation 7(17), viewed 29 April 2015, from http://PAREonline.net/getvn. asp?v=7\&n=17

Uchendu, O.A., 1993, 'The economic cost of electricity outages: Evidence from a sample study of industrial and commercial firms in the Lagos area of Nigeria', CBN Economic and Financial Review, Vol 31(3), 183 - 195.

Ukpong, I.I., 1973, 'The economic consequences of electric power failures', The Nigerian Journal of Economic and Social Studies 2, 90-120.
Vachani, S., 1994, 'The impact of economic liberalisation on small companies' competitiveness', Small Enterprise Development 5(4), 41-46. http://dx.doi. org/10.3362/0957-1329.1994.039

Van Wijnbergen, S., 1986, 'Exchange rate management and stabilization policies in developing countries', Journal of Development Economics 23(2), 227-247. http:// dx.doi.org/10.1016/0304-3878(86)90117-3

Vickery, J., 2008, 'How and why do small firms manage interest rate risk?', Journal of Financial Economics 87, 446-470. http://dx.doi.org/10.1016/j.jfineco.2006. 09.011

Wheeler, D. \& Mody, A., 1992, 'International investment location decisions: The case of U.S. Finns', Journal of International Economics 33(1-2), 57-76. http://dx.doi. org/10.1016/0022-1996(92)90050-T

Wiggins, S.N., 1995, 'Entrepreneurial enterprises, endogenous ownership, and the limits to firm size', Economic Inquiry 33(1), 54-69. http://dx.doi.org/ 10.1111/j.1465-7295.1995.tb01846.x

Wong, P.K., Ho, Y. P. \& Autio, E., 2005, 'Entrepreneurship, innovation and economic growth: Evidence from GEM data', Small Business Economics 24(3), 335-350. http://dx.doi.org/10.1007/s11187-005-2000-1

World Bank, 1993, Energy Sector Management Assistance Programme Report on Nigeria, World Bank, Washington, DC.

World Bank, 2005, Report on the Observance of Standards and Codes (ROSC): Corporate governance country assessment - Ghana, viewed 16 February 2014, from http://0www.worldbank.org.ujlink.uj.ac.za/ifa/Ghana\%20ROSC $\% 20$ final\%20 (formatted). pdf

World Bank, 2013, 'Nigeria economic report', viewed 17 February 2014, from http:// documents.worldbank.org/curated/en/2013/05/17708026/nigeria-economic report

World Bank, 2014, Building integrated markets within the East African Community EAC opportunities in public-private partnership approaches to the region's infrastructure needs, International Bank for Reconstruction and Development/ World Bank, Washington, DC. 